\title{
Influenza A virus and Reye's syndrome in adults
}

\author{
LARRY E DAVIS AND MARIOKOR NFELD \\ From the Neurology Service, Veterans Administration Medical Center and Department of Neurology \\ and Pathology, University of New Mexico School of Medicine, Albuquerque, New Mexico
}

SU M M ARY We report fatal Reye's syndrome in two adults following proven influenza A viral infections. Reye's syndrome is, therefore, not confined to children but may also occur in adults. Many reported cases of postinfluenza A encephalopathy have clinical and pathological features of Reye's syndrome suggesting that they are not due to postinfectious perivenous demyelination.

In 1963, Reye, Morgan, and Baral described 21 children who, following a prodromal illness, developed vomiting, seizures, coma and death. ${ }^{1}$ Noninflammatory cerebral oedema and fatty metamorphosis of the liver was found at necropsy. An increasing number of similar cases have since been reported worldwide. Reye's syndrome is generally thought to occur only in children. The aetiology is unknown, but the syndrome has been associated with epidemics of influenza $B$ virus ${ }^{2}$ and varicella zoster virus. ${ }^{3}$

We describe two adults with mild influenza virus illness followed by clinical, biochemical and pathologic features of Reye's syndrome. We suggest that this syndrome can occur in adults in association with influenza $\mathrm{A}$ virus infections.

\section{Case reports}

Case 1 A 57 year old, previously healthy, white male developed fever, cough and myalgia on 6 March 1978, during an epidemic of influenza A/Victoria/3/75. The patient was mildly ill and was recovering. Three days later vomiting, confusion and seizures developed. $\mathrm{He}$ was hospitalised with a temperature of $38.9^{\circ} \mathrm{C}$, stuporous with bilateral Babinski signs. No papilloedema or focal neurological signs were present. The liver was not enlarged and no other abnormalities were present. The patient rapidly progressed into a coma with fixed, dilated pupils and absent reflexes. The next day the electroencephalogram (EEG) showed electrocerebral silence and the patient

Address for reprint requests: Dr Davis, Department of Neurology, University of New Mexico School of Medicine, Albuquerque, NM 87131 USA.

Accepted 1 December 1979 died. No one in his family had ever had illnesses suggesting abnormalities of the urea cycle.

Laboratory tests included a normal brain computerised tomogram (CT), blood count, and serum electrolytes. A traumatic lumbar puncture done on admission had a normal opening pressure. The cerebrospinal fluid (CSF) contained 900 fresh red blood cells per $\mathrm{mm}^{3}, 5$ lymphocytes per $\mathrm{mm}^{3}, 250$ $\mathrm{mg}$ per dl protein, $150 \mathrm{mg}$ per dl glucose, and sterile bacterial and fungal cultures. The SGOT level was 114 milli-International Units per $\mathrm{ml}$ $(\mathrm{mIU} / \mathrm{ml}$ ) (normal 9 to 41 ) and lactic dehydrogenase (LDH) level was $800 \mathrm{mIU} / \mathrm{ml}$ (normal 60 to 100). Total serum bilirubin was normal. Toxicology studies demonstrated moderate salicylate levels in the blood, but no toxins.

Case 2 An 18 year old waitress with no previous health problems became ill with influenza. Two days later, she developed nausea and vomiting. The next day confusion and seizures developed. Initial neurological examination was normal except for confusion. Five hours after admission, she became comatose without localising signs. Three hours later the patient had fixed dilated pupils, absent reflexes, and no spontaneous respirations. An EEG showed electrocerebral silence. She was maintained on a respirator for four days before death. She had had no previous episodes of encephalopathy or liver disease and there was no family history of individuals with abnormalities of the urea cycle.

Laboratory tests included a normal blood count, serum electrolytes, drug and toxin screen, skull $\mathrm{x}$-ray and isotope brain scan. Lumbar puncture showed a normal opening pressure. The CSF contained $95 \mathrm{RBC}$ per $\mathrm{mm}^{3}$, no WBCs, $23 \mathrm{mg}$ per dl protein, $105 \mathrm{mg}$ per dl glucose, nonreactive 
Venereal Disease Research Laboratory results, and sterile bacterial and fungal cultures. On admission the SGOT was $198 \mathrm{mIU}$ per $\mathrm{ml}, \mathrm{LDH}$ was 250 $\mathrm{mIU}$ per $\mathrm{ml}$, and serum total bilirubin was normal; these tests remained abnormal thereafter.

\section{Necropsy findings of cases 1 and 2}

Brain The brains were swollen with flattened gyri, narrow sulci, and compressed ventricles. They weighed 1580 grams in case 1 and 1330 grams in case 2. Histological findings in both brains were similar. There were numerous empty pericellular, perivascular, and interfibrillary spaces in sections from all parts of the cerebrum. Within the convolutional white matter, there was astrocytosis with swollen, often lobulated nuclei and pale, eosinophilic, ill-defined cell bodies. Microgliosis was also present. Blood vessels within the brain were dilated and rare foci of recent haemorrhage could be seen. No inflammatory cells were seen in meninges, brain parenchyma, or spinal cord. There were no defects of myelin in the brain or spinal cord. Many cells in the choroid plexus contained cytoplasmic vacuoles (fig 1). These vacuoles were similar to those described in Reye's syndrome by Brown and Madge. ${ }^{4}$

Liver The livers of both patients were normal in size and shape. Histologically, fine vacuoles were present in most of the hepatocytes which did not displace the nucleus (fig 2). Numerous fine lipid droplets in hepatocytes were seen on the oil red 0 stain (fig 2 inset). These lipid droplets were of ten present in higher concentrations at the periphery of the lobules and were typical of fatty metamorphosis found in Reye's syndrome.

Kidney Case 1 had normal kidneys. Case 2 had fine lipid droplets in the cells of the collecting tubules.

Lungs There were foci of bronchopneumonia and disseminated zones of atelectasis in both cases.

\section{Virology and serological studies}

Viral cultures were obtained in case 1 from cardiac blood, trachea, frontal, temporal and occipital cortex, and thoracic and lumbar spinal cord. No virus isolation studies were attempted on the other case. Influenza virus was isolated from ten-day embryonated eggs following intra-amniotic inoculation with $10 \%$ suspension of trachea and thoracic spinal cord. The other tissue samples contained no virus. Both influenza isolates were identified as influenza A/Victoria/75 at the World Health Organization Influenza Reference Laboratory at the Center for Disease Control, Atlanta, GA.

Serological studies on blood obtained at nec-

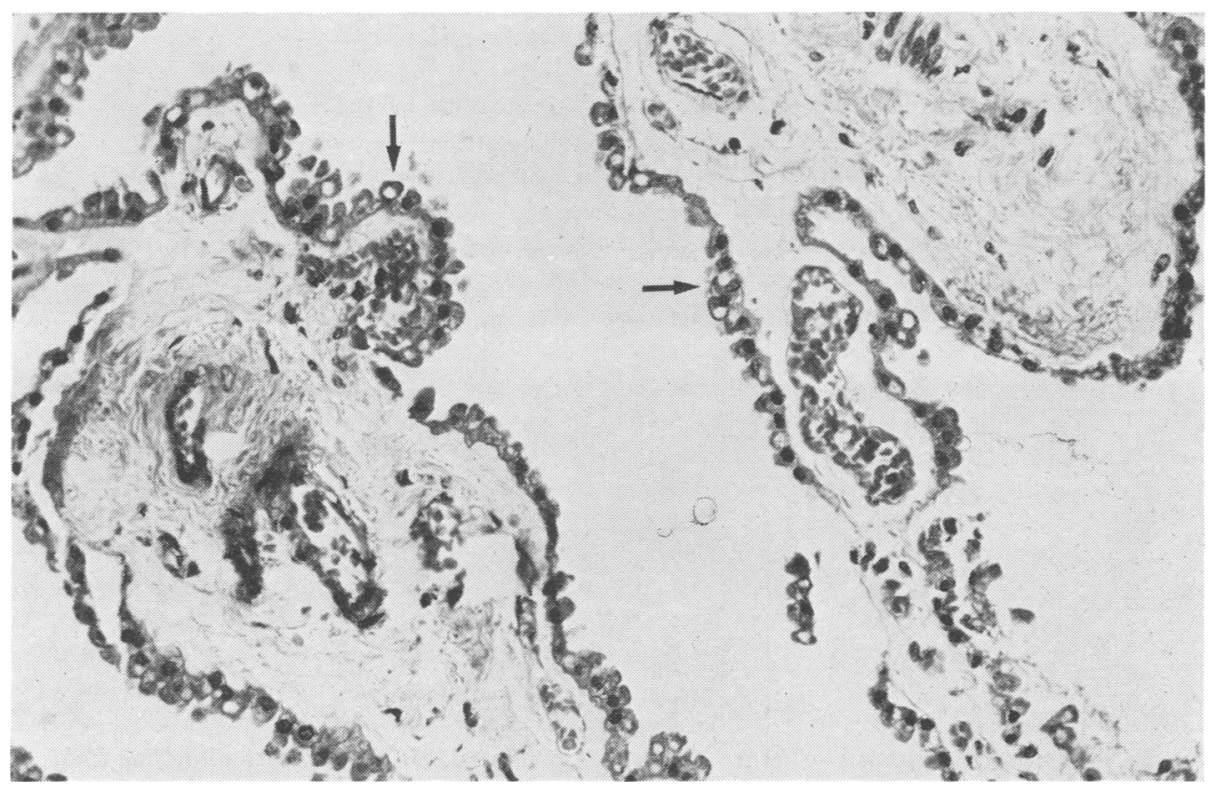

Fig 2 Fatty metamorphosis of liver; $A$ (case 1), B (case 2), $H \& E$. Insets show fine lipid eosin (original magnification $\times 64)$. 


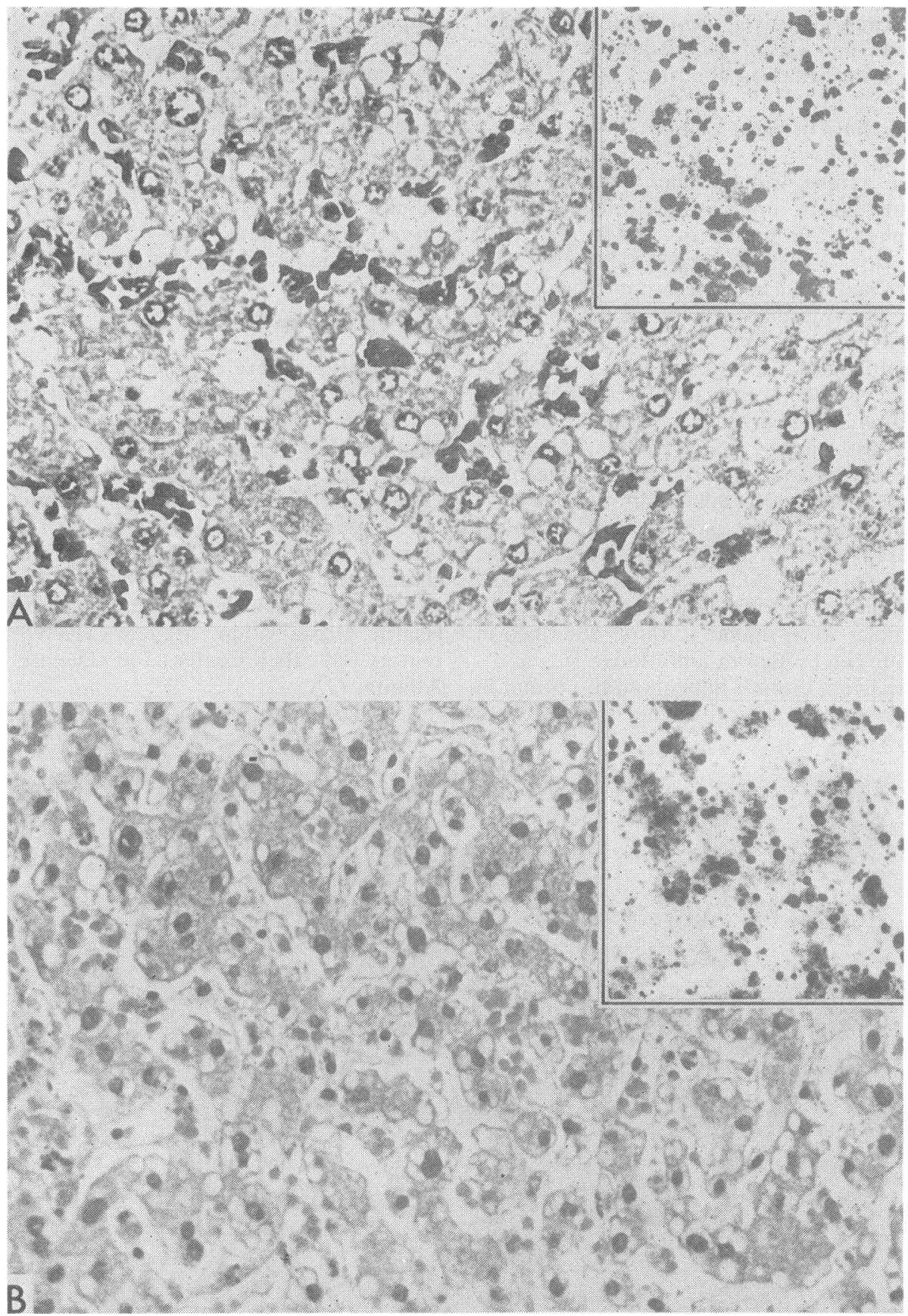

Fig 2 Fatty metamorphosis of liver; $A$ (case 1), B (case 2), $H \& E$. Insets show fine lipid droplets within hepatocytes, oil red $O$ (original magnifications $\times 130$ ). 
ropsy of case 2 showed a complement fixation (CF) titre of $1: 1024$ against influenza $A$ virus antigen and a titre of $1: 16$ against influenza $B$ viral antigen. The influenza $A$ antibody titre was considered by the WHO Influenza Reference Laboratory to demonstrate concomitant or recent infection with influenza $A$ virus. No CF antibodies to western equine encephalitis. Venezuelan encephalitis and Saint Louis encephalitis viruses were present.

\section{Discussion and review of literature}

In both cases, the diagnosis was not made before death. Prothrombin times, ammonia levels, and ultrastructure of the liver were, therefore, not available. In retrospect, both cases presented with typical features of Reye's syndrome. There was a mild influenza illness followed by an abrupt onset of vomiting, seizures and an encephalopathy terminating in death. Biochemical evidence of hepatocellular damage and severe fatty metamorphosis of the liver were found. Toxic causes of acute liver damage were not found. Cerebral oedema without inflammatory or demyelinating changes were present. Thus, the clinical and pathologic criteria for the diagnosis of Reye's syndrome were met in both cases. ${ }^{5}$ Virological or serological evidence of an acute influenza $A$ virus infection was present. This suggests the association of Reye's syndrome with influenza A virus in these patients.

Although Reye's syndrome has been associated with prior influenza $B^{2}$ and varicella virus ${ }^{3}$ infections, a virus has only rarely been recovered from the liver or brain. ${ }^{6}$ The isolation of influenza $\mathrm{A}$ virus from the spinal cord of case 1 is difficult to interpret as it was recovered in only one of seven brain and spinal cord samples and histological examination of the spinal cord did not suggest a myelitis.

Central nervous system complications of influenza $A$ virus infection are often called influenza encephalomyelitis. This term is used to describe patients of all ages who developed stupor, coma, and seizures following influenza. The pathology is often described in textbooks as a postinfectious encephalitis, with perivenous demyelination of the white matter. ${ }^{78}$

To determine how often central nervous system

Table Fatal cases of proven influenza $A$ virus infection and encephalopathy

\begin{tabular}{|c|c|c|c|c|c|c|c|c|}
\hline $\begin{array}{l}\text { First } \\
\text { author }\end{array}$ & $\begin{array}{l}\text { Case } \\
\text { number }\end{array}$ & $\begin{array}{l}\text { Agel } \\
\text { sex }\end{array}$ & $\begin{array}{l}\text { Vomiting } \\
\text { preceding } \\
\text { neurological } \\
\text { symptoms }\end{array}$ & Seizure & $\begin{array}{l}\text { Normal } \\
\text { CSF }\end{array}$ & $\begin{array}{l}\text { Duration of } \\
\text { neurological } \\
\text { symptoms to } \\
\text { death (days) }\end{array}$ & $\begin{array}{l}\text { Liver } \\
\text { dysfunction } \\
\text { and/or fatty } \\
\text { degeneration }\end{array}$ & $\begin{array}{l}\text { Brain oedema } \\
\text { without } \\
\text { inflammation or } \\
\text { demyelination }\end{array}$ \\
\hline Horner $^{26}$ & 4 & $14 / F$ & + & - & + & 1 & - & + \\
\hline \multirow{3}{*}{ Flewett $^{10}$} & $1 \mathrm{~A}$ & $11 / \mathbf{M}$ & + & - & + & 1 & 0 & + \\
\hline & 1B & 3 & 0 & + & 0 & 0 & 0 & + \\
\hline & $1 \mathrm{C}$ & 4 & 0 & + & 0 & 0 & 0 & + \\
\hline \multirow[t]{2}{*}{ Oseasohn ${ }^{17}$} & 17 & $10 / \mathrm{F}$ & + & - & + & 1 & 0 & + \\
\hline & 27 & 9/M & - & + & 0 & 1 & 0 & + \\
\hline Ongerboer ${ }^{\circ}$ & 1 & $48 / \mathrm{M}$ & - & - & - & 30 & + & $-\mathbf{a}$ \\
\hline \multirow[t]{6}{*}{ Kapila $^{18}$} & 1 & 0 & + & + & + & 3 & + & + \\
\hline & 3 & 0 & + & - & + & 3 & + & + \\
\hline & 5 & 0 & + & - & + & 3 & + & + \\
\hline & 17 & 0 & + & + & + & 6 & + & + \\
\hline & 24 & 0 & + & - & + & 2 & + & + \\
\hline & 28 & 0 & + & + & + & 5 & + & + \\
\hline Bamatter $^{10}$ & 1 & $15 / \mathrm{F}$ & + & + & + & 1 & 0 & + \\
\hline Horvath"4 & 1 & $64 / F$ & 0 & - & + & 1 & + & + \\
\hline Bennett ${ }^{20}$ & 1 & $16 / \mathrm{F}$ & + & + & + & 1 & 0 & + \\
\hline Beswick $^{21}$ & 3 & $19 / \mathrm{F}$ & - & - & 0 & 5 & - & 0 \\
\hline Hall $^{22}$ & 1 & $13 / \mathrm{F}$ & + & - & + & 3 & + & + \\
\hline Joshi ${ }^{11}$ & 1 & $1 / 12 / \mathrm{M}$ & - & - & 0 & 12 & + & + \\
\hline Nicholls ${ }^{10}$ & 2 & $10 / \mathrm{M}$ & - & + & + & 60 & + & $-b$ \\
\hline Crandall ${ }^{23}$ & 1 & 6/M & + & + & + & 5 & - & + \\
\hline Kajii's & 6 & $10 / M$ & 0 & 0 & 0 & 2 & - & + \\
\hline Finland ${ }^{25}$ & A-1 & $18 / \mathrm{F}$ & + & + & 0 & 1 & 0 & 0 \\
\hline \multirow[t]{2}{*}{ Noble"c } & 1 & $14 / M$ & + & + & 0 & 3 & + & + \\
\hline & 2 & $5 / F$ & + & + & 0 & 4 & + & + \\
\hline \multirow[t]{2}{*}{ Ruben 26} & 4 & $8 / \mathrm{F}$ & + & 0 & 0 & 8 & + & 0 \\
\hline & 5 & $12 / \mathrm{M}$ & + & 0 & 0 & 6 & + & 0 \\
\hline \multirow{3}{*}{$\begin{array}{l}\text { Murphy } \\
\text { Present }\end{array}$} & 1 & $44 / F$ & 0 & 0 & 0 & 4 & - & + \\
\hline & 1 & $57 / M$ & + & + & + & 1 & + & + \\
\hline & 2 & $18 / F$ & + & + & + & 4 & + & + \\
\hline
\end{tabular}

$+=$ present $;-=$ absent; $0=$ not reported; $a=$ coexistent EB virus infection present $; b=$ late in clinical course a brain abscess developed; $c=$ two cases on Reye's syndrome file at Center for Disease Control, Atlanta, Georgia. 
complications of influenza A infection were actually postinfectious encephalitis or were likely to have been Reye's syndrome, a review of the literature was undertaken. A summary of 30 cases dying of encephalopathy and proven influenza $\mathbf{A}$ viral infection is given in the table. Cases without virological or serological confirmation were excluded. In those cases where details were available, the median age of onset was 12 years with a range of one month to 64 years. Fifty-five per cent of the cases were female. The mean duration from onset of neurological symptoms to death was six days. Vomiting preceded neurological symptoms in $67 \%$, seizures developed in $50 \%$, and coma occurred in all. The CSF was abnormal in only $4 \%$. Changes in the brain, other than cerebral oedema, were found in two cases, and both had evidence of coexisting infection with Epstein-Barr virus ${ }^{9}$ or a fungal brain abscess. ${ }^{10}$ Twenty-seven per cent of reports did not mention liver function studies or morphological findings in the liver. Nevertheless, liver dysfunction was noted in $57 \%$ and fatty degeneration was found in $40 \%$. We conclude, therefore, that most cases of proven influenza $A$ encephalopathy have histological evidence of brain oedema without inflammation or demyelination. Over half also have clinical evidence of liver dysfunction or fatty degeneration at necropsy. We suggest that some cases previously called "influenza encephalopathy" or "postinfectious influenza encephalopathy" were, in fact, Reye's syndrome.

Several investigators have suggested that Reye's syndrome results from sudden defects in the urea cycle enzymes. ${ }^{28}{ }^{29}$ Neither of our cases had a past history or family history suggesting urea cycle abnormalities. However, since we did not measure blood ammonia or liver urea cycle enzyme levels, we cannot consider this hypothesis further.

Our two cases of Reye's syndrome in adults emphasise that the disease is not confined to children. The syndrome occurs in infants, ${ }^{11-13}$ as well as adults. ${ }^{914} 30$ The diagnosis must, therefore, be considered in patients of all ages who suddenly develop vomiting, seizures, and coma, particularly during an influenza epidemic.

The authors thank Robert List, MD, Allen Jones, MD, Sonia Hollinger, MD, John Sullivan-Bolyai, MD, Brenda Mitchell, Linda Cole, Gena Gomez, Jane Bates, and Leroy McLaren, PhD, for their assistance in this study.

The work was supported by the Research Service, Veterans Administration, USPHS and Reye's Syndrome Society, Albuquerque, New Mexico Chapter.

\section{References}

1 Reye RDK, Morgan G, Baral J. Encephalopathy and fatty degeneration of viscera: A disease entity in childhood. Lancet 1963; 2:749-52.

2 Corey L, Rubin RJ, Hattwick MAW, Noble GR, Cassidy E. A nationwide outbreak of Reye's syndrome: Its epidemiologic relationship to influenza B. Am J Med 1976; 61:615-25.

3 Glick TH, Ditchek NT, Salitsky S, Freimuth EJ. Acute encephalopathy and hepatic dysfunction. Association with chickenpox in siblings. Am J Dis Child 1970; 119:68-71.

4 Brown RE, Madge GE. The choroid plexus in Reye's syndrome. VA Med Mon 1972; 99:271-5.

5 Corey L, Rubin RJ, Bregman D, Gregg MB. Diagnostic criteria for influenza B associated with Reye's syndrome: Clinical vs. pathologic criteria. Pediatrics 1977; 60:702-7.

6 Noble GR, Corey L, Rubin RJ. Virologic components of Reye's syndrome. In: Pollack JD ed. Reye's Syndrome. New York: Grune \& Stratton, 1975:189-97.

7 Harter DH, Meritt HH. Infections. In: Merritt HH ed. $A$ Textbook of Neurology, 6th ed. Philadelphia: Lea \& Febiger Publishing Co, 1979:102.

8 Gilroy J, Meyer JS. Medical Neurology, 2nd ed. New York, Macmillan Publishing Co. 1975:1956.

9 Ongerboer de Visser BW, Dankmeijer HF, Bots AM, Endtz LJ. Hypothalamic polio-encephalitis in influenza A preceded by mononucleosis. $J$ Neurol Sci 1976; 29:33-8.

10 Nicholls S, Gill D, Craske J. Reye's syndrome associated with acute tubular necrosis. Arch Dis Child 1975; 50:960-2.

11 Joshi VV, Escobar MR, Stewart L, Bates RD. Fatal influenza $\mathrm{A}_{2}$ viral pneumonia in a newborn infant. Am J Dis Child 1973; 126:839-40.

12 Papageorgiou A, Wiglesworth FW, Schiff D, Stern L. Reye's syndrome in a newborn infant. Can Med Ass J 1973; 109:717-20.

13 Harris HB, Vogler LB, Cassady G. Reye's syndrome in a neonate. Southern Med J 1976; 69: 1511-12.

14 Horvath S, Balazs V. A case of fatal Asian influenza with encephalitic signs. Wiener Klinische Wochenschrift 1959; 71:239-40.

15 Horner FA. Neurologic disorders after Asian influenza. New Eng J Med 1958; 258:983-5.

16 Flewett TH, Hoult JG. Influenzal encephalopathy and postinfluenzal encephalitis. Lancet 1958; 2: 11-15.

17 Oseasohn R, Anderson L, Kaji M. Clinicopathologic study of 33 fatal cases of Asian influenza. $N$ Engl J Med 1959; 260:509-18.

18 Kapila CC, Kaul S, Kapur SC, Kalayanam TS, Banerjee D. Neurological and hepatic disorders associated with influenza. Brit Med J 1958; 2: 1311-14.

19 Bamatter F, Gautier A, Jeanneret O, Paccaud MF, Wildi E. A case of influenza encephalitis 
with isolation of influenza A/Asian/57 virus from the central nervous system. Schweizerische Medizinische Wochenschirft 1961; 91:567-71.

20 Bennett AE, Turk RE. Acute encephalitis and death following Asian influenza. Calif Med 1957; 87:411-12.

21 Beswick IP, Finlayson R. A renal lesion in association with influenza. J Clin Path 1959; 12: 280-5.

22 Hall BD, Highes WT, Kinetz D. Reye's syndrome: An association with influenza A infection. J Kentucky Med Ass 1969; 67:269-71.

23 Crandall RA, Dowdle WR, Holcomb TM, Dahl EV. A fatal illness associated with two viruses: An intermediate adenovirus type (21-16) and influenza $\mathrm{A}_{2}$. J Pediat 1968; 72:467-73.

24 Kaji M, Oseasohn R, Jordan WD, Dingle JH. Isolation of Asian virus from extrapulmonary tissues in fatal human influenza. Proc Soc Exp Biol Med 1959; 100:272-5.

25 Finland M, Barnes MW, Samper BA. Influenza virus isolations and serological studies made in Boston during the winter 1943-1944. J Clin Invest 1945; 24:192-208.

26 Ruben FL, Michaels RH. Reye's syndrome with associated influenza $\mathrm{A}$ and $\mathrm{B}$ infection. $\mathrm{J} A \mathrm{Am}$ Med Ass 1975; 234:410-12.

27 Murphy AM, Hawkes RA. Neurological complications of influenza A2/Hong Kong/68 virus. Med J A ustr 1970; 2:511.

28 Thaler MM. Pathogenesis of Reye's syndrome. A working hypothesis. Pediatrics 1975; 56:1081-4.

29 Brown T, Hug G, Lansky L, Bove K, Scheve A, Ryan M, Brown H, Schubert WK, Partin JC, Lloyd Still J. Transiently reduced activity of carbamyl phosphate synthetase and ornithine transcarbamylase in liver of children with Reye's syndrome. N Eng J Med 1976; 294:861-6.

30 Varma RR, Riedel DR, Komorowski RA, Harrington GJ, Nowak TV. Reye's syndrome in nonpediatric age groups. J Am Med Assoc 1979; 242: 1373-5. 